\title{
Acinar Cell Adenoma
}

National Cancer Institute

\section{Source}

National Cancer Institute. Acinar Cell Adenoma. NCI Thesaurus. Code C4196.

A benign glandular epithelial neoplasm consisting of secretory cells forming acinar patterns. 